Vol. 5 (1996): 601-608.

Research Note

\title{
Occurrence of common scab in potato tubers after foliar treatment with glycinebetaine under glasshouse conditions
}

Elina Tuomola

Department of Plant Production, P.O. Box 27, FIN-00014 University of Helsinki, Finland

Hannu Rita

Department of Forest Resource Management / Statistics, P.O. Box 24, FIN-00014 University of Helsinki, Finland

Paavo Kuisma

Potato Research Institute, Ruosuontie 156, FIN-16900 Lammi, Finland

Susanne Somersalo, Eija Pehu

Department of Plant Production, P.O. Box 27, FIN-00014 University of Helsinki, Finland

Kari Jokinen

Cultor Ltd., Finnsugar Bioproducts, P.O. Box 105, FIN-00241 Helsinki, Finland

Jari P.T. Valkonen

Department of Plant Production, P.O. Box 27, FIN-00014 University of Helsinki, Finland. Present address: Institute of Biotechnology, P.O. Box 56, FIN-00014 University of Helsinki, Finland, e-mail: jari.valkonen@ helsinki.fi

A single foliar spray with $2.5 \mathrm{mM}$ glycinebetaine (GB) was applied on potato (Solanum tuberosum L.) cvs. Matilda, Sabina and Saturna grown in a sand bed infested with Streptomyces scabies (Thaxter) Waksman \& Henrici at tuber initiation. A period of drought was maintained after GB treatment to enhance scab infection. Logit models were used to compare scab incidence in all harvested tubers (n $=622)$ and the type of scab in the symptomatic tubers $(\mathrm{n}=382)$, whereas the tuber surface areas covered with scab lesions were compared using ANOVA. A $10 \mathrm{~g}$ increase in tuber weight increased the odds of scab incidence by $11.3 \%$. Scab incidence was lowest in Sabina and highest in Matilda. Raised scab and superficial scab were common in all cultivars, but pitted scab developed only in a few tubers of Sabina and Matilda. Among the scabby tubers, the incidence of raised scab was highest in Sabina and lowest in Saturna. The mean surface area covered with scab was $32.8 \%$ in Matilda, $11.7 \%$ in Saturna and $7.5 \%$ in Sabina. Treatment with GB slightly reduced the severity of scab symptoms, as shown by the reduction in the proportion of tubers with raised scab among the scabby tubers (odds 0.60 ). No effect on the incidence of scab or the tuber area covered with scab lesions was detected following GB treatment.

Key words: disease control, logit model, potato, Solanum tuberosum, Streptomyces scabies 


\section{AGRICULTURAL AND FOOD SCIENCE IN FINLAND}

Tuomola, E. et al. Effect of glycinebetaine on common scab in potato

\section{Introduction}

The scab disease of potato (Solanum tuberosum L.) is caused by the actinomycete species of the genus Streptomyces. S. scabies (Thaxter) Waksman \& Henrici causes common scab in most areas where potatoes are grown, but there are also other species of Streptomyces which cause symptoms similar to common scab or symptoms described as russet or netted scab (Hooker 1981, Scholte and Labruyere 1985, Keinath and Loria 1989, Doering-Saad et al. 1992, Faucher et al. 1992). Common scab occurs as three types of symptoms which impair the quality of tubers: superficial scab, raised scab (cushionlike or erumpent) and pitted scab (extension into the tuber) (reviewed by Locci 1994). Here, unless otherwise stated, the term scab refers to common scab caused by $S$. scabies.

The type of scab and the proportion of the tuber surface covered with scab correlate with and are determined by the level of susceptibility of the potato cultivar (Leach et al. 1938, Bjor and Roer 1980, Goth et al. 1991). In contrast, the incidence of scab in tubers is determined by environmental factors such as soil $\mathrm{pH}$ and moisture. Scab incidence can be lowered by bringing $\mathrm{pH}$ below 5.2 , but this practice also reduces the availability of nutrients to potato plants (Martin 1923, Loria 1991). Maintenance of soil moisture close to field capacity by irrigation during the first 4-5 weeks of tuber formation can greatly reduce scab incidence (Martin 1923, Lapwood et al. 1973). However, irrigation can increase the incidence and severity of other soil-borne diseases (Loria 1991) and does not always reduce scab (Goto 1985, Doering-Saad et al. 1992).

Potato cultivars vary in their resistance to scab, but no cultivar is fully resistant (Bjor and Roer 1980, Loria 1991). Attempts have therefore been made to reduce scab in potato by affecting the physiology of potato plants through chemical treatments. Foliar spray with the growth retardants daminozine and 3,5-dichlorophenoxyacetic acid (3,5-D) reduces scab in tubers. Both compounds improve tuber resist- ance to scab rather than have bactericidal effects on the pathogen (McIntosh 1979, McIntosh et al. 1981, Burrell 1984, McIntosh et al. 1988).

Glycinebetaine (GB) is a compatible solute which accumulates naturally in the cells of some plant species under osmotic stress, but is not synthesized in many important crop species, e.g., potato (Gorham 1995). GB stabilizes cell membranes (Jolivet et al. 1982) and certain photosynthetic structures (Papageorgiou et al. 1991). The physiological role of GB has not been fully established but it may act as an osmoregulatory compound (Robinson and Jones 1986). As higher scab incidences coincide with dry soil and drought stress of potato plants in the field (Martin 1923, Loria 1991), it is suggested that the reduction in drought stress achieved with GB treatment might also reduce scab incidence. This hypothesis is supported by unpublished findings of P. Kuisma and K. Jokinen from potato field plots sprayed with GB. In this study, we tested the effects of GB treatment on potato common scab under controlled glasshouse conditions.

\section{Material and methods}

\section{Experimental design}

Potato cvs. Matilda, Sabina and Saturna were chosen for the experiments because they are commonly grown in Finland and, as shown by observations in the field, seem to differ in susceptibility to scab, Matilda being the most highly susceptible. On the other hand, Saturna is the most sensitive to drought, which may result in a significantly reduced mean tuber size under dry growth conditions (L. Pietilä and P. Kuisma, unpublished). Pathogen-tested minitubers were obtained from the Seed Potato Center, Tyrnävä, Finland.

S. scabies strains SSC110 and SSC122 isolated from potato cvs. Record and Bintje, respectively, infected in the field in Jokioinen, Finland, and known to cause severe scab symptoms on 


\section{AGRICULTURAL AND FOOD SCIENCE IN FINLAND}

\section{Vol. 5 (1996): 601-608.}
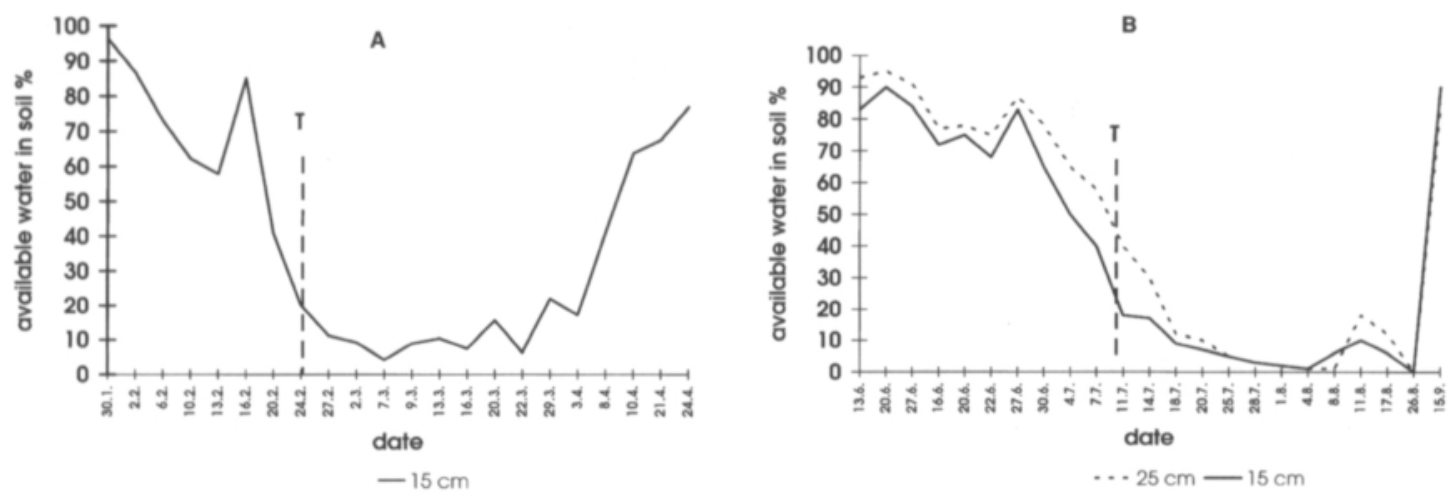

Fig. 1. Available water (A) at $15 \mathrm{~cm}$ depth in the sand bed in the glasshouse during this study, and (B) at 15 and $25 \mathrm{~cm}$ depths in soil of the potato test plots in the field at the Potato Research Institute, Lammi, in 1994, from emergence to maturity of potato plants. T, time of a single spray with glycinebetaine.

potato (Oravuo 1994), were kindly provided by J. Kankila, Plant Breeding Section, Institute of Plant and Soil Science, Agricultural Research Centre, Finland. They were grown on potato dextrose agar (Difco) for 3 weeks at $24^{\circ} \mathrm{C}$, each suspended in 101 of sterile distilled water $(5.4 \mathrm{x}$ $10^{6}$ colony-forming units per $\mathrm{ml}$ ) and mixed into a bed of fine sand $(6.0 \times 1.1 \mathrm{~m}$, depth of sand 35 $\mathrm{cm})$ in the glasshouse. The sand was fertilized using an N:P:K fertilizer (8:10:12) at $75 \mathrm{~kg} \mathrm{~N} / \mathrm{ha}$. Tubers were sprouted at room temperature (mean sprout length $5 \mathrm{~mm}$ ) and planted in a sand bed on January 9. The plants were arranged in three blocks in the bed, each block including ten plants of each cultivar in two rows (five plants per row). The moisture in the sand bed was monitored at seven measurement points using the Bouyoucos Moisture Meter (Industrial Instruments, Michigan State Board of Agriculture, Cedar Grove, Essex, N.J., USA) and was adjusted by irrigation to simulate the fluctuation of soil moisture in the field plots at the Potato Research Station during the 1994 growth season (Fig. 1). The plants were grown under natural daylight extended to $18 \mathrm{~h}$ by illumination with sodium halide lamps (150-1100 $\left.\mathrm{mols}^{-1} \mathrm{~m}^{-2}\right)$. Daily mean temperatures were $20^{\circ} \mathrm{C}\left(17-25^{\circ} \mathrm{C}\right)$.

The time for GB treatment was selected to correspond to the growth stage of the potato plants and the soil moisture in order to mimic the application time in the field in 1994. Within each block, one row (five plants) of each cultivar was treated with a single foliar spray of 2.5 mM GB (pH 8.0) (Cultor Ltd. Finnsugar Bioproducts, Finland) diluted with distilled water 6 weeks after planting. At this time, flower buds had formed in all cultivars but they had not yet opened. The amount of GB used for the treatment corresponded to $1.17 \mathrm{~kg} / \mathrm{ha}$. Control plants were sprayed with distilled water.

\section{Data analysis}

The tubers were lifted on May 3 (124 days after planting). The tuber surface area covered by scab was determined with the method described by Schöber (1984). Each tuber was also evaluated for the type of scab: no scab, superficial scab, raised scab or pitted scab (Hooker 1981). This classification was appropriate, as each tuber showed only one type of scab.

ANOVA containing five factors (cultivar, GB treatment, tuber weight class, scab type and block) was used to detect differences in the mean surface area covered by scab; only tubers showing scab symptoms were analysed (SAS Institute Inc., General Linear Models Procedure). Scab incidence and type were analysed in two stages. First, the response was reduced to a bi- 


\section{AGRICULTURAL AND FOOD SCIENCE IN FINLAND}

Tuomola, E. et al. Effect of glycinebetaine on common scab in potato

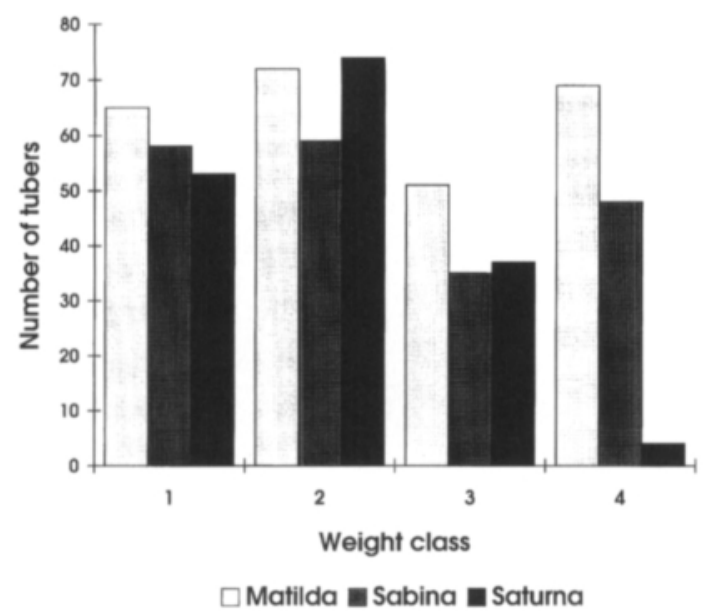

Fig. 2. Distribution of 622 harvested tubers by weight. 1, $<10 \mathrm{~g} ; 2,10-29 \mathrm{~g} ; 3,30-50 \mathrm{~g} ; 4,>50 \mathrm{~g}$.

nary variable indicating only the incidence of scab, irrespective of its type. Second, to analyse the type of scab, only scabby tubers were included. Only a few tubers showed pitted scab (Table 1), and so were excluded from analysis. Thus, the type of scab also became a binary variable (superficial or raised scab). Logit models are suitable for analysing data with a binary response (Collett 1991) and can be powerful tools in many kind of studies on plants (Mäkäräinen et al. 1994, Linden et al. 1996, Malkamäki et al. 1996). Thus, both response variables, i.e., the incidence and the type of scab, were analysed using logit models (SAS Institute Inc., GenMod Procedure).

The test potato cultivars were of similar maturity types. Tuber weight (size) and age do not strictly correlate, but it is expected that the weight classes of the largest and smallest tubers contain the most mature and juvenile tubers, respectively (Burton 1989). The length of time available for the development of scab symptoms is proportional to tuber age, because infection occurs when tubers are young (Adams and Lapwood 1978, Hooker 1981). It was therefore considered important to test whether tuber age, as indirectly and roughly indicated by weight, had any effect on scab. Because the mean tuber weight differed among the test cultivars (Fig. 2), tubers of each cultivar were divided into four weight classes with an equal number of tubers in each class.

\section{Results}

\section{Surface area covered by scab}

A total of 382 tubers of the 622 tubers harvested from the three cultivars had some form of scab (Table 1). Analysis of the surface area covered with scab using ANOVA showed that cultivars differed $(\mathrm{p}=0.0001)$ : the mean surface area covered with scab was greatest in Matilda $(32.8 \%$ coverage), intermediate in Saturna (11.7\%) and lowest in Sabina $(7.5 \%)(p=0.001)$. Tubers in the higher weight classes and with raised scab had a larger surface area covered by scab lesions $(\mathrm{p}=0.0001$ and $\mathrm{p}=0.002$, respectively) than did those with superficial scab. The tuber weight class $x$ scab type $x$ block interaction was significant $(\mathrm{p}=0.002)$ whereas the other interactions were non-significant. No effect due to GB treatment could be detected.

\section{Incidence of scab}

Tuber weight was significantly associated with scab incidence (Table 2), but had no interaction with GB treatment or cultivar $(\mathrm{p}=0.24$ and $\mathrm{p}=$ 0.48 , respectively). An increase of the tuber weight by $10 \mathrm{~g}$ increased the odds of scab incidence by $11.3 \%$. Scab incidence was lowest in Sabina, intermediate in Saturna and highest in Matilda (Table 2). Treatment with GB had no effect on scab incidence $(p=0.41)$ and no interaction with cultivars $(\mathrm{p}>0.13)$.

\section{Type of scab}

Raised scab and superficial scab were the most common types of scab observed (Table 1). 
Vol. 5 (1996): 601-608.

Table 1. The numbers (and percentages) of tubers with different types of scab after treatment of plants with a single foliar spray with glycinebetaine. Controls were sprayed with distilled water. $(n=622)$

\begin{tabular}{lcccccc}
\hline & \multicolumn{2}{c}{ cv. Matilda } & \multicolumn{2}{c}{ cv. Sabina } & \multicolumn{2}{c}{ cv. Saturna } \\
& treated & control & treated & control & treated & control \\
\hline a) No scab & $31(24.6 \%)$ & $30(23.3 \%)$ & $52(50.5 \%)$ & $52(53.6 \%)$ & $31(44.9 \%)$ & $44(44.9 \%)$ \\
b) Pitted scab & $3(2.4 \%)$ & $5(3.9 \%)$ & $1(1.0 \%)$ & $6(6.2 \%)$ & 0 & 0 \\
c) Superficial or raised scab & $92(73.0 \%)$ & $94(72.8 \%)$ & $50(48.5 \%)$ & $39(40.2 \%)$ & $38(55.1 \%)$ & $54(55.1 \%)$ \\
- - superficial scab & $65(70.7 \%)$ & $58(61.7 \%)$ & $14(28.0 \%)$ & $7(17.9 \%)$ & $38(100 \%)$ & $52(96.3 \%)$ \\
- raised scab & $27(29.3 \%)$ & $36(38.3 \%)$ & $36(72.0 \%)$ & $32(82.1 \%)$ & 0 & $2(3.7 \%)$ \\
Total $(\mathrm{a}+\mathrm{b}+\mathrm{c})$ : & $126(100 \%)$ & $129(100 \%)$ & $103(100 \%)$ & $97(100 \%)$ & $69(100 \%)$ & $98(100 \%)$ \\
\hline
\end{tabular}

Table 2. Logit analysis of scab incidence (including the differences between blocks).

\begin{tabular}{lcccr}
\hline Comparison & Coefficient & $\begin{array}{c}\text { P-value } \\
\text { (Wald test) }\end{array}$ & O.R. ${ }^{a}$ & C.I. $^{{ }^{b}}$ \\
\hline $\begin{array}{l}\text { Treated vs. control } \\
\text { Cultivar }\end{array}$ & -0.01 & 0.95 & 0.99 & $0.71-1.39$ \\
$\quad$ Sabina vs. Matilda & -1.29 & & & \\
$\quad$ Saturna vs. Matilda & -1.00 & 0.00 & 0.28 & $0.18-0.41$ \\
Weight $^{c}$ & 0.11 & 0.00 & 0.37 & $0.24-0.56$ \\
\hline
\end{tabular}

a.R., odds ratio. O.R. = 1 is equivalent to no difference in the comparison. O.R. different from 1 is interpreted as follows: for example, O.R. $=0.99$ (lower than 1) indicates that the incidence of scab in the treated plants is lower than in the control plants.

${ }^{b}$ C.I., 95\% confidence interval. If unity $=1$ is within the C.I., this indicates that the comparison does not show a significant difference $(\mathrm{p}=0.05)$.

${ }^{c}$ per $10 \mathrm{~g}$ increase in tuber weight.

Table 3. Logit analysis of scab type (including the differences between blocks).

\begin{tabular}{lcccc}
\hline Comparison & Coefficient & $\begin{array}{c}\text { P-value } \\
\text { (Wald test) }\end{array}$ & O.R. $^{{ }^{a}}$ & C.I. $^{\text {b }}$ \\
\hline $\begin{array}{l}\text { Treated vs. control } \\
\text { Cultivar }\end{array}$ & -0.51 & 0.06 & 0.60 & $0.36-1.01$ \\
$\quad$ Sabina vs. Matilda & 1.89 & 0.00 & 6.60 & $3.67-11.87$ \\
$\quad$ Saturna vs. Matilda & -3.19 & 0.00 & 0.04 & $0.01-0.17$ \\
\hline
\end{tabular}

a O.R., odds ratio. O.R. $=1$ is equivalent to no difference in the comparison. For the interpretation of O.R. differing from 1, see Table 2.

${ }^{b}$ C.I., 95\% confidence interval. If unity $=1$ is within the C.I., this indicates that the comparison does not show a significant difference $(p=0.05)$.

Among the scabby tubers, the incidence of raised scab was highest in Sabina, intermediate in Matilda, and lowest in Saturna (Table 3). Pitted scab developed in only a few tubers of Sabina and Matilda and, as mentioned above, was not included in statistical analysis. Weight and the GB 


\section{AGRICULTURAL AND FOOD SCIENCE IN FINLAND}

Tuomola, E. et al. Effect of glycinebetaine on common scab in potato

treatment by cultivar interaction were not significant $(p>0.37)$. Some reduction in raised scab, which was close to the statistically significant level ( $\mathrm{p}=0.0566)$, was observed among the scabby tubers in all cultivars combined (odds 0.60 ) following GB treatment (Table 3).

\section{Discussion}

The three potato cultivars studied here differed in their response to common scab. Sabina had the lowest incidence of scab, but symptoms were severe in those tubers which developed scab symptoms; the most common type was raised scab, although pitted scab was also observed in a few tubers. The incidence of scab was also low in Saturna but symptoms were mild (superficial scab). Matilda showed the highest incidence of scab, the largest surface area covered by scab and all three types of scab. Many previous studies have suggested that the type of scab and the tuber surface area covered with scab lesions indicate the relative level of resistance to scab in potato cultivars, whereas the incidence of scab in tubers is dependent on environmental factors such as soil $\mathrm{pH}$ and moisture (Martin 1923, Leach et al. 1938, Bjor and Roer 1980, Goth et al. 1991, Loria 1991). Thus, the incidence of scab seems to be associated with the initial infection process, whereas the type of scab and the surface area covered with scab are associated with physiological processes in the tuber which take place after infection and result in the formation of scab lesions. Neither the process of infection of potato tubers by S. scabies nor the development of scab symptoms is well-described at the molecular and physiological level. The production of cell wall-degrading enzymes by $S$. scabies is, however, known to play a role in penetration and that of the vivotoxin thaxtomin in symptom development (Adams and Lapwood 1978, Hooker 1981, Lawrence et al. 1990, Locci 1994). The environmental conditions in our study were the same for all three cultivars. Differences between cultivars were, however, observed in all three of the above variables implying that each can be affected by the cultivar. It is therefore suggested that Sabina resists infection but not symptom development, Saturna resists both infection and symptom development, but that Matilda has little resistance to either.

Severe occurrence of common scab in potatoes in the field is known to be associated with drought and can usually be controlled by irrigation, but the reasons for these phenomena are not understood (Martin 1923, Adams and Lapwood 1978, Loria 1991). For example, it is not known whether the conditions in dry soil are more beneficial to $S$. scabies, which is aerobic, and, thus, exacerbate the virulence of the pathogen, or whether the drought stress of potato plants increases their susceptibility to the scab disease, or whether both mechanisms are involved. Here, we tested the latter hypothesis by treating potato plants with $\mathrm{GB}$, a solute thought to mitigate drought stress (Robinson and Jones 1986, Agboma et al. 1996). Our results suggested that the severity of scab symptoms was reduced by GB treatment, as a slightly smaller proportion of tubers showed raised scab. The proportion of tubers with pitted scab also seemed to be lower after GB treatment (Table 1), but this was not tested statistically. It should be noted that not all observations were independent, as several tubers from a single plant were included in the analysis and, thus, the statistical significance of results should be treated with some caution. Because GB treatment had no significant effect on the incidence of infection (i.e., the incidence of scabby tubers), it is suggested that GB affected the physiology of potato tubers and subsequently the development of symptoms, rather than the initial infection by $S$. scabies. Raised scab was more common in tubers with a larger surface area covered with scab lesions $(\mathrm{p}=0.002)$. However, the extent of the tuber surface area covered with scab lesions was not reduced by GB treatment. Although the treatment seemed to reduce symptom severity it may not have been strong enough to reduce lesion area. 
Vol. 5 (1996): 601-608.

The molecular action of GB in potato cells is not fully understood. It is known that GB is translocated in potato plants (P. Mäkelä, E. Tuomola, J. Valkonen and S. Somersalo, unpublished). It is hypothesized then that GB is translocated from foliage to tubers, thus affecting scab development via changes in plant physiology rather than via direct antimicrobial activity, as shown previously for some other compounds (McIntosh 1979, McIntosh et al. 1981, Burrell 1984, McIntosh et al. 1988).

Foliarly applied GB has increased yields of tomato (Lycopersicon esculentum Mill., Solanaceae), the highest yield increases having been achieved at an application rate of 1-2 kg/ ha (Mäkelä et al., unpublished), and also of many grain crops, under drought (Agboma et al. 1996). The application rate of GB used for potato in our study was at the lower limit of an effective application rate for tomato, a factor that may partially explain the lack of effect on tuber yield. The use of higher amounts of GB might also control scab more efficiently.

Acknowledgements: Financial support from Cultor Ltd. Finnsugar Bioproducts and the Academy of Finland is gratefully acknowledged.

\section{References}

Adams, M.J. \& Lapwood, D.H. 1978. Studies on the lenticel development, surface microflora and infection by common scab (Streptomyces scabies) of potato tubers growing in wet and dry soils. Annals of Applied Biology 90: 335-343.

Agboma, P.C., Jones, M.G.K., Peltonen-Sainio, P., Rita, H. \& Pehu, E. 1996. Exogenous glycinebetaine enhances grain yield of maize, sorghum and wheat grown under two supplementary watering regimes. Journal of Agronomy and Crop Science, in press.

Bjor, T. \& Roer, L. 1980. Testing the resistance of potato varieties to common scab. Potato Research 23: 33-47. Burrell, M.M. 1984. Inhibition of browning, phenoxyacetic acids and phenolic metabolism in potato tuber discs: a model system to study chemicals that control common scab. Plant Pathology 33: 325-336.

Burton, W.G. 1989. The potato. 3rd ed. Longman Scientific \& Technical, New York, USA. 742 p.

Collett, D. 1991. Modelling binary data. Chapman \& Hall, London, UK. 369 p.

Doering-Saad, C., Kämpfer, P., Manulis, S., Kritzman, G., Schneider, J., Zakrzewska - Czerwinska, J., Schrempf, H. \& Barash, I. 1992. Diversity among Streptomyces strains causing potato scab. Applied and Environmental Microbiology 58: 3932-3940.

Faucher, E., Savard, T. \& Beaulieu, C. 1992. Characterization of actinomycetes isolated from common scab lesions on potato tubers. Canadian Journal of Plant Pathology 14:197-202.

Gorham, J. 1995. Betaine in higher plants: biosynthesis and role in stress metabolism. In: Wallsgrove, R.M. (ed.). Aminoacids and their derivatives in higher plants. University Press, Cambridge, UK. p. 172-203.

Goth, R.W., Haynes, K.G. \& Wilson, D.R. 1991. Evaluation and characterization of advanced potato breeding clones for resistance to scab by cluster analysis. Plant Disease 77:911-914.

Goto, K. 1985. The relative importance of precipitation and sugar content in potato peel for the detection of the incidence of common scab (Streptomyces scabies). Soil Science and Plant Nutrition 31: 419-425.

Hooker, W.J. 1981. Compendium of potato diseases. The American Phytopathological Society, St. Paul, MN, USA. p. 33-34.

Jolivet, Y., Larher, F. \& Hamelin, J. 1982. Osmoregulation in halophytic higher plants: the protective effect of glycine betaine against the heat destabilization of membranes. Plant Science Letters 25:193-201.

Keinath, A.P. \& Loria, R. 1989. Population dynamics of Streptomyces scabies and other actinomycetes as related to common scab of potato. Phytopathology 79: 681687.

Lapwood, D.H., Wellings, L.W. \& Hawkins, J.H. 1973. Irrigation as a practical means to control potato common scab (Streptomyces scabies): final experiment and conclusions. Plant Pathology 22: 35-41.

Lawrence, C.H., Clark, M.C. \& King, R.R. 1990. Induction of common scab symptoms in aseptically cultured potato tubers by the vivotoxin, thaxtomin. Phytopathology 80: 606-608.

Leach, J.G., Krantz, F.A., Decker, P. \& Mattson, H. 1938. The measurement and inheritance of scab resistance in selfed and hybrid progenies of potatoes. Journal of Agricultural Research 56: 843-853.

Linden, L., Rita, H. \& Suojala, T. 1996. Logit models for estimating lethal temperatures in apple. HortScience 31: 91-93.

Locci, R. 1994. Actinomycetes as plant pathogens. European Journal of Plant Pathology 100: 179-200. Loria, R. 1991. Potato scab. In: Diseases of potato. New 


\title{
AGRICULTURAL AND FOOD SCIENCE IN FINLAND
}

Tuomola, E. et al. Effect of glycinebetaine on common scab in potato

York State Integrated Pest Management Program Fact Sheet. Cornell Cooperative Extension, Ithaca, NY, USA. p. 725.80

Mäkäräinen, E., Rita, H., Teperi, E. \& Valkonen, J.P.T. 1994. Resistance to Spongospora subterranea in tuberbearing and non tuber-bearing Solanum spp. Potato Research 37: 123-127.

Malkamäki, U., Clark, M.S., Rita, H., Valkonen, J.P.T. \& Pehu, E. 1996. Analyses of solanaceous species using repetitive genomic DNA sequences isolated from Solanum brevidens. Plant Science 117: 121-129.

Martin, W.H. 1923. Influence of soil moisture and acidity on the development of potato scab. Soil Science 16: 6973.

Mclntosh, A.H. 1979. Decreased common scab incidence after foliar sprays of daminozide. Potato Research 22: 361-363.

-, Bateman, G.L. \& Chamberlain, K. 1988. Substituted benzoic and picolinic acids as foliar sprays against potato common scab. Annals of Applied Biology 112: 397401.

- , Bateman, G.L., Chamberlain, K., Dawson, G.W. \& Burrell, M.M. 1981. Decreased severity of potato com- mon scab after foliar sprays of 3,5-dichlorophenoxyacetic acid, a possible antipathogenic agent. Annals of Applied Biology 99: 275-281.

Oravuo, M. 1994. Applicability of a "pot method" for testing susceptibility to common scab (Streptomyces scabies) and for selection of breeding materials. M.S. Thesis, Department of Plant Production, University of Helsinki, Finland. 75 p. (In Finnish).

Papageorgiou, Gr.C.M., Fujimura, Y. \& Murata, N. 1991. Protection of the oxygen-evolving photosystem II complex by glycinebetaine. Biochimica et Biophysica Acta 1057: 361-366.

Robinson, S.P. \& Jones, G.P. 1986. Accumulation of glycinebetaine in chloroplasts provides osmotic adjustment during salt stress. Australian Journal of Plant Physiology 13: 659-668.

Scholte, K. \& Labruyere, R.E. 1985. Netted scab: a new name for an old disease in Europe. Potato Research 28: 443-448.

Schöber, B. 1984. Methoden zur Prūfung der Anfälligkeit von Kartoffelknollen für den Gewöhnlichen Schorf. In: Potato Disease Assessment Keys. European Association for Potato Research, Wageningen, The Netherlands.

\section{SELOSTUS}

\section{Glysiinibetaiinilla suoritetun lehvästöruiskutuksen vaikutus perunan rupisuuteen}

\author{
Elina Tuomola, Hannu Rita, Paavo Kuisma, Susanne Somersalo, Eija Pehu, Kari Jokinen ja Jari Valkonen \\ Helsingin yliopisto, Perunantutkimuslaitos ja Cultor Finnsugar Bioproducts, Finland
}

Perunaruven torjunta viljelyteknisin menetelmin on ongelmallista. Perunan fysiologiaan vaikuttavien ja ruven syntyä estävien kemiallisten aineiden kehittäminen tehostaisi ruven torjuntaa. Tässä tutkimuksessa perunarupea aiheuttavalla sädebakteerilla (Streptomyces scabies) saastutettuun hiekkapetiin istutettujen perunoiden (Matilda, Sabina ja Saturna) lehvästö ruiskutettiin glysiinibetaiinilla mukulanmuodostuksen alkaessa. Kontrolli ruiskutettiin tislatulla vedellä. Käsittelyn jälkeen kasvualustan annettiin olla jonkin aikaa normaalia kuivempana rupi-infektion edistämiseksi. Rupisten mukuloiden ja eri rupityyppien osuuksia sekä ruven peittämän pinta-alan eroja verrattiin. Riippumatta käsittelystä ja lajikkeesta, mukulan koon kasvaessa ruven esiintymisen todennäköisyys kasvoi. Rupisten mukuloiden osuus oli suurin Matildassa ja pienin Sabinassa. Myös ruven peittämä mukulan pinta-ala oli suurin Matildassa ja pienin Sabinassa. Laakarupi ja kohorupi olivat yleisiä kaikissa lajikkeissa, mutta syvärupea oli vain muutamissa Sabinan ja Matildan mukuloissa. Kohorupea oli eniten Sabinassa ja vähiten Saturnassa. Glysiinibetaiinikäsittely vähensi lievästi rupioireiden ankaruutta kaikissa lajikkeissa, mikä ilmeni kohorupisten mukuloiden osuuden vähenemisenä, mutta rupisten mukuloiden osuuteen ja ruven peittämään mukulan pinta-alaan sillä ei havaittu olevan vaikutusta. 